OPEN ACCESS

Approved by:

Olivier Feron,

Université catholique de Louvain,

Belgium

${ }^{*}$ Correspondence:

Frontiers Editorial Office

editorial.office@frontiersin.org

Specialty section:

This article was submitted to

Pharmacology of Anti-Cancer Drugs,

a section of the journal

Frontiers in Oncology

Received: 07 June 2021 Accepted: 07 June 2021

Published: 29 June 2021

Citation:

Frontiers Editorial Office (2021)

Retraction: Combination of

Tanshinone IIA and Cisplatin Inhibits

Esophageal Squamous Cell

Carcinoma by Down-Regulating

NF-kB/COX-2NEGF Pathway.

Front. Oncol. 11:721658.

doi: 10.3389/fonc.2021.721658

\section{Retraction: Combination of} Tanshinone IIA and Cisplatin Inhibits Esophageal Squamous Cell Carcinoma by Down-Regulating NF-kB/COX-2/VEGF Pathway

\author{
Frontiers Editorial Office* \\ Frontiers Media SA, Lausanne, Switzerland
}

\section{A Retraction of the Original Research Article}

Combination of Tanshinone IIA and Cisplatin Inhibits Esophageal Cancer by Downregulating NF-KB/COX-2/VEGF Pathway

by Liao, X., Gao, Y., Liu, J., Tao, L., Xie, J., Gu, Y., Liu, T., Wang, D., Xie, D., \& Mo, S. (2020). Front. Oncol. 10:1756. doi: 10.3389/fonc.2020.01756

The Journal retracts the September 10, 2020 article cited above for the following reason:

Following publication, concerns were raised regarding the integrity of the images in the published figures. The authors failed to provide a satisfactory explanation during the investigation, which was conducted in accordance with Frontiers' policies.

This retraction was approved by the Chief Editors of Frontiers in Oncology and the Chief Executive Editor of Frontiers. The authors did not agree to this retraction.

Copyright $(2021$ Frontiers Editorial Office. This is an open-access article distributed under the terms of the Creative Commons Attribution License (CC BY). The use, distribution or reproduction in other forums is permitted, provided the original author(s) and the copyright owner(s) are credited and that the original publication in this journal is cited, in accordance with accepted academic practice. No use, distribution or reproduction is permitted which does not comply with these terms. 